\title{
The Development of Experimental Electronic Student Activity Sheet (E-LKPD) using The Guided Inquiry Learning Model on Blood Circulation System Materials for Class XI SMA/MA
}

\author{
Suci Seftiani ${ }^{1}$, Wan Syafii ${ }^{2}$, Zulfarina ${ }^{2}$ \\ ${ }^{1}$ Postgraduate Student of FKIP Riau University, Pekanbaru, 28293, Indonesia \\ ${ }^{2}$ Advisors I, and II Postgraduate FKIP Riau University, Pekanbaru, 28293, Indonesia
}

\section{ARTICLE INFO}

\section{Article history:}

Received: 07 June 2021

Revised: 11 Jan 2022

Accepted: 12 Jan 2022

Published online: 24 Jan 2022

Keywords:

e-LKPD

Guided Inquiry

Kvisoft Flipbook Maker

\begin{abstract}
A B S T R A C T
This e-LKPD research used a guided inquiry learning model which aimed at analyzing the effect of e-LKPD on improving cognitive learning outcomes of high school students on the material of the circulatory system. The study used the One Group Pretest-Posttest design model with the research subjects of class XI MIPA 3. At the beginning of the implementation students were given pretest questions, then students studied e-LKPD using a guided inquiry learning model and were given posttest questions. This e-LKPD was developed using the ADDIE model. This model consists of 5 stages of development, namely the Analyze, Design, Development. Implementation and Evaluation stages. The results of the research on the development of e-LKPD showed that: The feasibility value by media experts was very valid 3.76 (94) and the feasibility value of material experts was very valid 3.42 (85.5). The feasibility value of practitioners was very good 3.79 (94.75). Students responses were very practical. The practicality test by students was called trial 13.59 (89.75) and trial 2 by students 3.64 (90.78). This showed that e-LKPD using the kvisoft flipbook maker produced in this research was considered feasible to be used in learning material of circulatory system. Cognitive learning outcomes of students using e-LKPD development results had increased from 30.4 to 90.35 with a high value increase (N-Gain: 0.85).
\end{abstract}

\section{Introduction}

Such rapid changes in the world of education and the influence of globalization have consequences in shaping the young generation who are ready to face the challenges of the $21 \mathrm{st}$ century. The $21 \mathrm{st}$ century is marked by the rapid

\footnotetext{
* Corresponding author.

E-mail: Suciseftiani377@gmail.com
} 
development of science and technology, especially information technology, therefore learning is needed that can prepare students to be science literate. Education is one of the important means that is believed to be able to support the progress of the nation, support future development and produce qualified, skilled and highly competitive human resources, because through education a person is able to increase their potential so that students are able to solve the problems they will face (Hotimah, 2008).

The potential developed through such learning can prepare students to survive in the face of education in the 21 st century and future challenges, by managing productive, creative, innovative, and affective learning processes in science. Learning using the e-LKPD media Kvisoft Flipbook Maker is a e-learning teaching materials that do not require paper, created without cost, flexible with time and place, abstract objects become contextual, and can be used online or offline (Syamsiah, 2019). Teaching materials are a collection of learning materials which systematically arranged according to what is set and allow students to learn. The teaching materials that the researchers mean here are teaching materials that can make students interested and interested in learning, these teaching materials are in the form of electronic student activity sheets (e-LKPD) with the inquiry learning method (National, 2006).

Inquiry is one of the effective ways that can help students improve thinking skills by using higher mental processes and critical thinking skills (Putria, 2019). Besides students master science concepts, learning with inquiry is also trained to research and solve a problem or question with existing facts (Astuti, 2013). Based on the results of observations in several schools in Rokan Hulu, it was known that some biology teachers rarely developed student activity e-sheets (e-LKPD) in the learning process. The teachers only used LKPD from the MGMP that were already available. There were no new innovations that had been developed and implemented in the learning process.

The LKPD used predominantly contains questions and solutions. In addition, practicum is rarely used in biology learning. If biology learning should be done with a practicum, usually the teacher replaces it with a demonstration in front of the class and students are asked to observe without doing it themselves so that the thinking ability of students cannot develop optimally. In working on the questions, students are often trained only on the ability to remember and understand the material. The ability to apply and analyze is rarely given to students. In fact, this ability can be trained through experiments (practicum) and supported by the appropriate LKPD. Numerous science teachers believe that practical work can lead students to learn better because they can all understand and remember things better if they do it alone. So it can be concluded that practical activities in the form of practicum can help students better understand the subject matter because they directly try and observe (Millar, 2009).

The schedule or time of the learning process also affects the cognitive learning outcomes of students. Observation results showed that SMA Negeri 1 Kabun did not have a fixed schedule of biology practicum activities. When students studied 
in the morning, the students were more concentrated and focused on the teaching and learning process. If the learning session was not enough, the teacher would move the practicum schedule during the day. When doing practicum during the day, a vast majority of students were tired because they had been active in the morning so they were no longer interested in the learning process. Several students even tend to be sleepy, noisy, wander around, tend to avoid being asked questions, and got bored quickly during the learning process. As a result, the learning process did not go well.

The difficulty of students in conducting practicum during COVID-19 at home is they do not have a practicum worksheet. Therefore, teaching materials in the form of e-LKPD are needed. The learning process will be able to run well if the teacher has innovation in managing the learning process (Permana, 2017). One of the innovations that can overcome these problems is the creativity of teachers in making and using various learning media to booste students' motivation and creativity of independently. Based on the background and symptoms found in the school, researchers were interested in conducting research with the title "Development of an experimental electronic student activity sheet (e-LKPD) using a guided inquiry learning model on the material of the circulatory system for class XI SMA/MA students.

\section{Methodology}

The type of research in this study used research and development or commonly abbreviated as R\&D. R\&D is a research method to develop products or improve products (Suryana, 2015). Based on the opinion of Sanjaya (2014), research and development is the process of developing and validating educational products. The electronic student activity sheet (e-LKPD) was developed using the ADDIE model. This model consists of 5 stages of development, namely the Analyze, Design, Development, Implementation and Evaluation stages (Sugiyono, 2016). After the LKPD developed was valid and feasible to be used, then the study was carried out at SMA 1 Kabun October 5 to December 30, 2020 in the odd semester of 2020/2021 starting from the analysis, validation, implementation, and evaluation stages. The types of data obtained in this reasearch: (1) the results of the validity of the e-LKPD from experts. Content validity was assessed by 3 validators, namely 1 media expert, 2 material experts and 4 practitioner experts.

(2) The practicality test and student response questionnaires from the results of Trial 1, distributed response questionnaires to 5 postgraduate students of FKIP Biology at the University of Riau, while for trial 2 the response questionnaire was distributed to 20 students of class XI MIPA SMA N 1 Kabun.

\section{Results and Discussion}

This research was a development research, namely the development of experimental student activity sheets (e-LKPD) using a guided inquiry learning model on the material of the circulatory system. This study used the ADDIE 
model design which consists of 5 stages, namely Analysis, Design, Development, Implementation, and Evaluation. This research was carried out in class XI IPA from October 05 to December 30, 2020 odd semester 2020/2021 with analysis, validation, implementation, and evaluation stages. The research was started from the validation stage of e-LKPD by validators to implementation to students. Prior to the implementation stage, the e-LKPD was first validated by 3 validators, namely 1 media expert, 2 material experts, and 4 expert practitioners.

The research continued to the LKPD implementation stage which was started with testing (2) practicality tests and student response questionnaires from the results of Trial 1, distributed response questionnaires to 5 postgraduate students of FKIP Biology at the University of Riau. While for trial 2, response questionnaires were distributed to 20 students of class XI MIPA SMA N 1 Kabun. The allocation of research time in class XI IPA in one week consisted of $3 \times 45$ minutes, where every week there were 2 meetings, namely on Wednesday at 13.50-15.15 WIB and Thursday at 08.45-10.50 WIB. Before applying the student activity sheet (eLKPD), an experiment was conducted using a guided inquiry learning model on the material of the circulatory system. First, students had a preetest which consisted of 25 questions to test the students' cognitive learning outcomes before e-LKPD treatment. The posttest which consists of 25 questions was to test the students' cognitive learning outcomes after e-LKPD treatment using the guided inquiry learning model. The learning outcomes increased after giving e-LKPD to students. The e-LKPD using the guided inquiry learning model was feasible to use.

Ikhwani (2021) states that e-LKPD is a student work guide to facilitate students in implementing learning activities in electronic form that can be seen on desktop computers, notebooks, smartphones, and mobile phones. Kvisoft Flipbook Maker is an application for creating e-books, e-lkpd, e-papers and e-magazines, not only in the form of text, with Kvisoft Flipbook Maker can insert images, graphics, sound, links and videos on LKPD (Hidayati, 2012). The steps of making the display of the e-LKPD using the Kvisoft Flipbook Maker were: the cover page was designed as attractive as possible to catch students' attention so that students become more enthusiastic in the learning process (Putria, 2019). The cover contained the logo of the university where research and development was being carried out, the title of the e-LKPD, the name of the subject, class and semester, the image used for the title of the E-LKPD, the year of manufacture, the identity of the author. The cover image can be seen in Figure 1. 


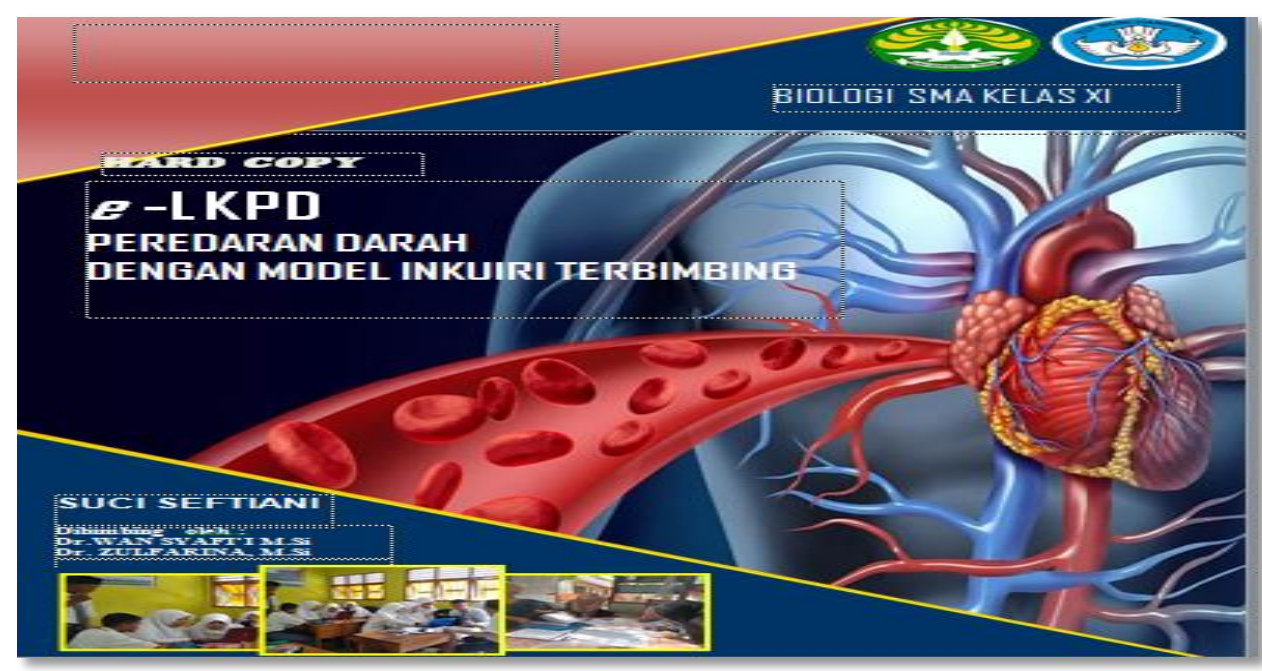

Figure 1. Cover of Blood Circulation e-LKPD With Guided Inquiry Model

This learning e-LKPD contained the syntax of 6 stages of guided inquiry learning activities. (1) problem orientation (2) making hypotheses (3) collecting data (4) analyzing data (5) making conclusions (6) doing reflection (Anggriyani, 2013) can be seen in Figure 2.

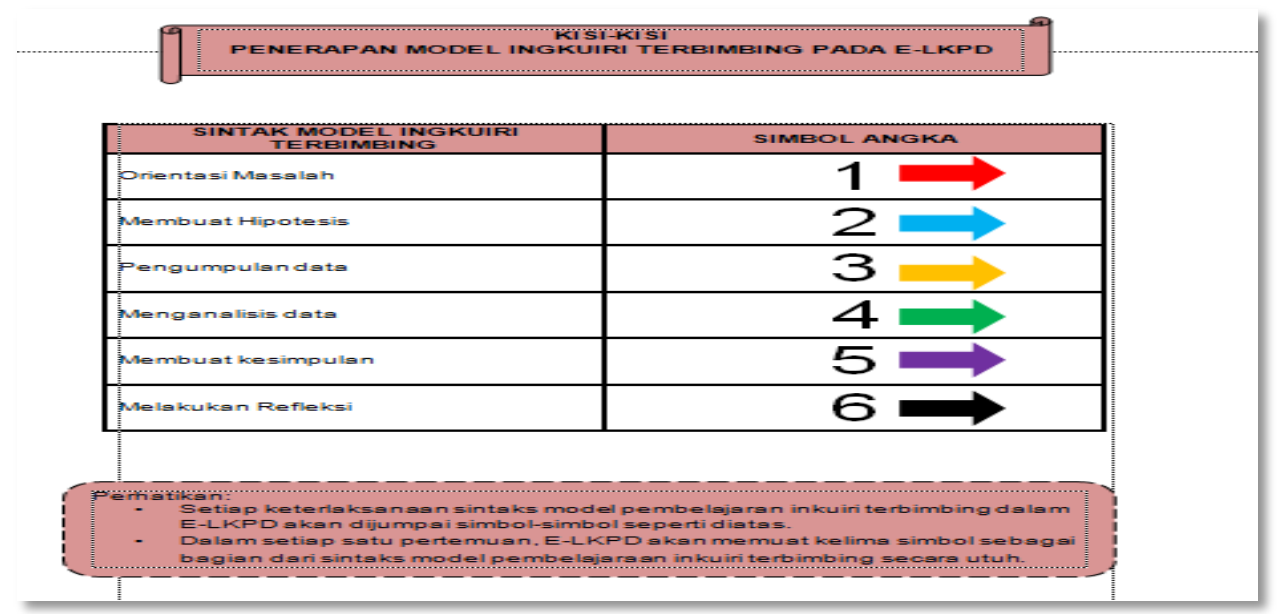

Figure 2. Syntax of e-LKPD Blood Circulation with a Guided Inquiry Model

Problem orientation was (1) The teacher guided the students to identify the problem and write it on the blackboard and the students read the discourse (2) The teacher divided the students into several groups. Making hypotheses were (1) The teacher provided opportunities for students to brainstorm in forming hypotheses (2) The teacher guided students in determining hypotheses relevant to the problem prioritizing hypotheses that would be used as investigations can be seen in Figure 3. 


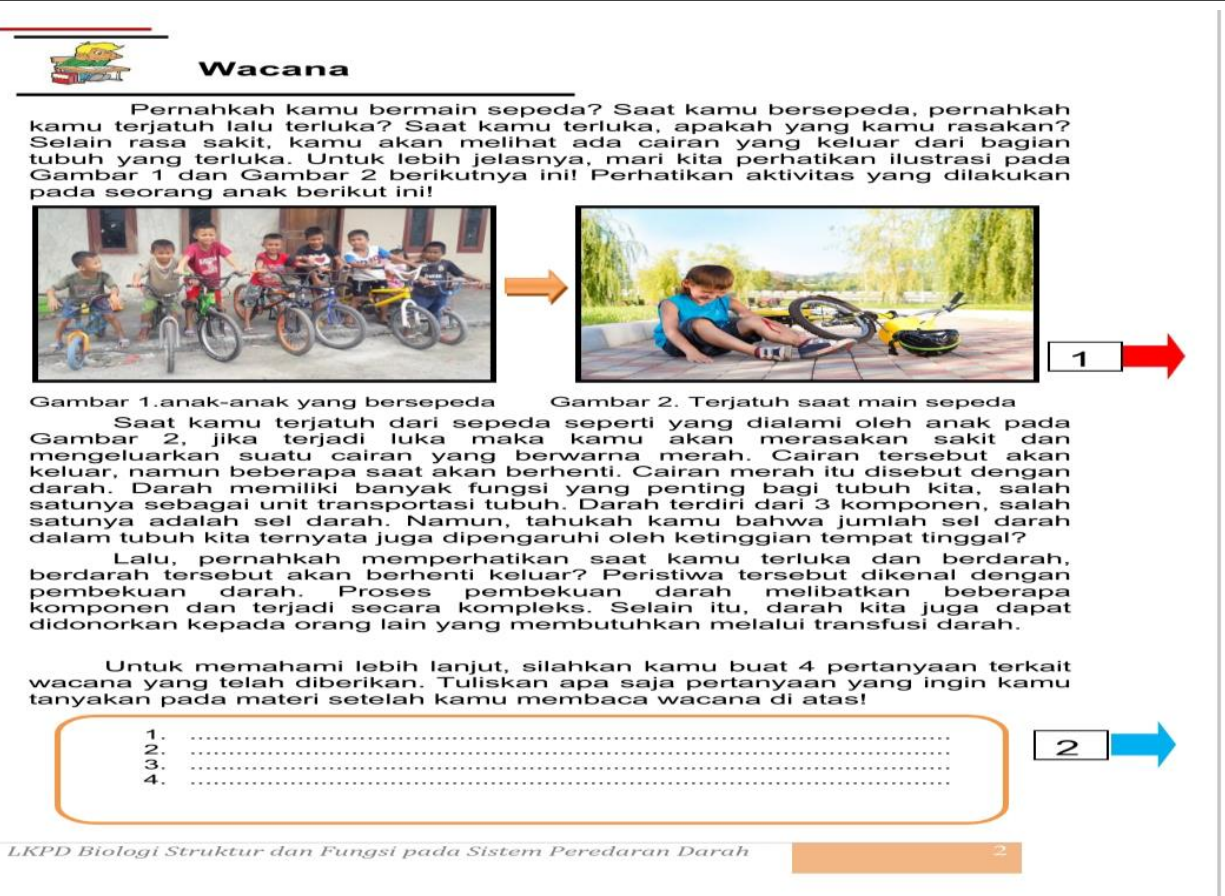

Figure 3. (1) Problem Orientation (2) Make a Hypothesis

Collecting data and analyzing data were (1) The teacher provided opportunities for students to determine the steps that were in accordance with the hypothesis that would be carried out (2) The teacher guided students in determining experimental steps (3) The teacher guided students to get data through experiments (4) The teacher provided an opportunity for each group to convey the results of processing the collected data can be seen in Figure 4.

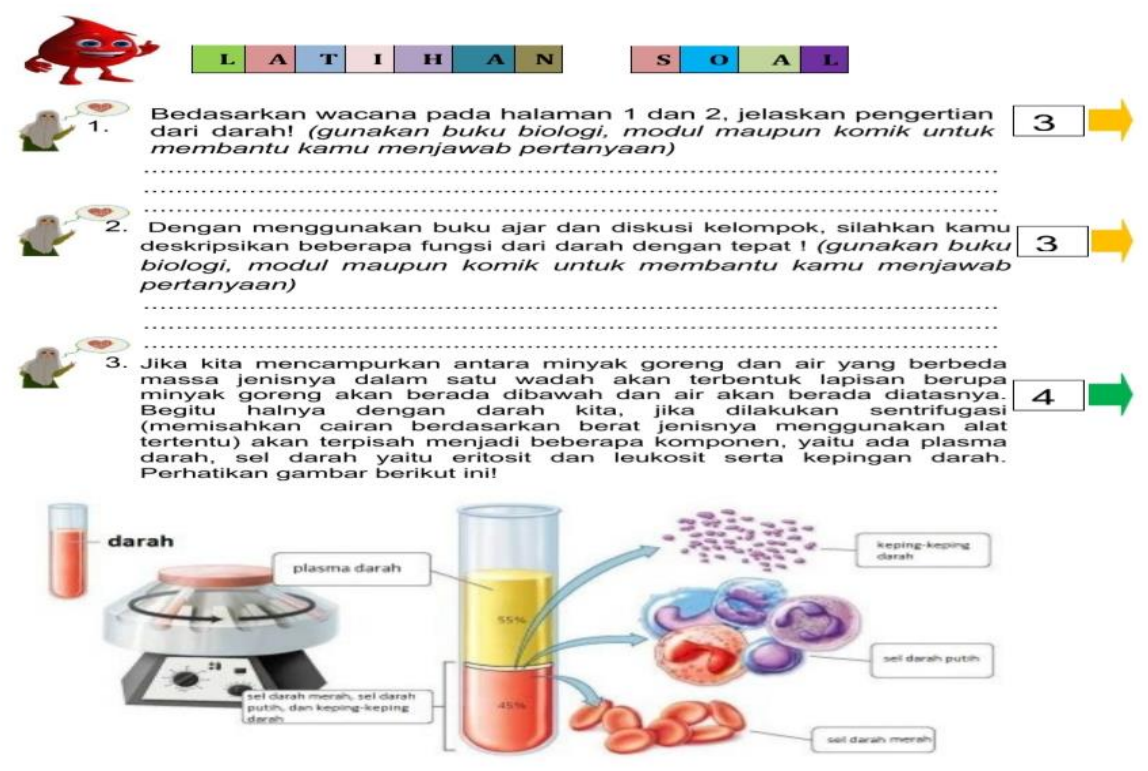

Gambar 3. llustrasi hasil sentrifugasi darah (sumber:google, 2020) LKPD Biologi Struktur dan Fungsi pada Sistem Peredaran Darah

Figure 4. (3) Data Collection (4) Analyzing Data 
Making conclusions was the teacher guiding students in making conclusions based on the data that had been obtained and reflecting to find out the understanding of the material for the human circulatory system can be seen in Figure 5.

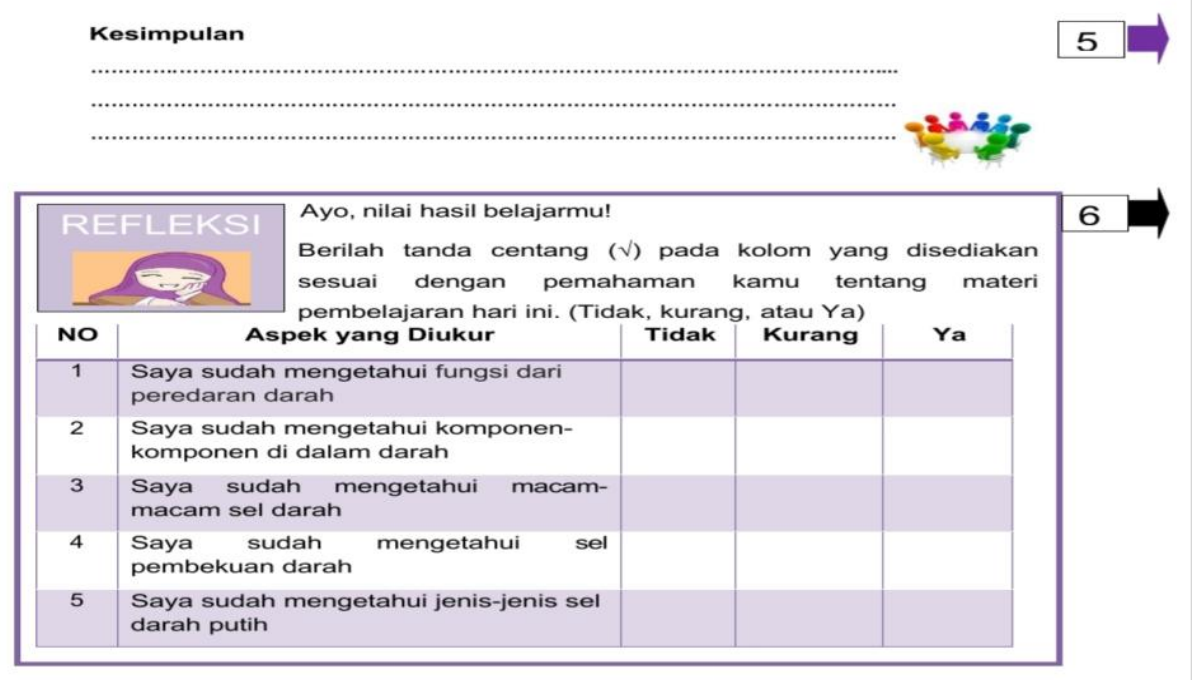

Figure 5. (5) Draw Conclusions (6) Reflect

The advantages of using e-LKPD are: save space and time, allows users to mark important things without scribbles, environmentally friendly, font size is adjustable and saving costs (Haqsari, 2014). The validity of the e-LKPD using the Kvisoft Flipbook Maker had been measured using the validity instruments namely: content validity assessed by 3 validators which consist of 1 media expert, 2 material experts, and 4 practitioner experts. The validators conducted an assessment with a validation sheet that covers programming aspects. Appearance, learning, material, and language can be seen in table 1 .

Table 1. Recapitulation of Experimental e-LKPD Validation using Guided Inquiry Model with KD 3.6 Human Circulatory System

\begin{tabular}{lrlcl}
\hline Evaluation & Average & Criteria & Overall Average & $\begin{array}{l}\text { Validity } \\
\text { Level }\end{array}$ \\
\hline Media Expert & 3,76 & Very valid & & \\
Material Expert & 3,42 & Very valid & 3,64 & Very Valid \\
Expert & 3,77 & Very valid & & \\
Practitioner & & & & \\
\hline
\end{tabular}

Table 1. Shows that media experts are 3.76 with very valid criteria, where the suitability of material experts is 3.42 with very valid criteria, the suitability of practitioner experts is 3.77 with very valid criteria. Overall, the e-LKPD had an average score of 3.64 in the Very valid category. Regarding to the validator in the field of education, the e-LKPD had been usable. However, there were inputs from expert validators that need to be improved in the e-LKPD. Illahi (2021) also argues that with validation by the education sector, the resulting LKPD will be more feasible and more perfect. 
The results of the practicality test were carried out with Trial 1 , namely the distribution of response questionnaires to 5 masters students of the Biology Faculty of the Universitas Riau. As for trial 2, the response questionnaire was distributed to 20 students of class XI MIPA SMA N 1 Kabun can be seen in table 2.

Table 2. Recapitulation of e-LKPD Validation in the Practical Test of KD 3.6 Human Circulatory System

\begin{tabular}{ccccc}
\hline Evaluation & Average & Criteria & Overall Average & Validity Level \\
\hline Testing 1 & 3,59 & Very Valid & & \\
Testing 2 & 3.64 & Very Valid & 3,60 & Very Valid \\
\hline
\end{tabular}

Table 2 shows that the practicality test in trial 1 averaged 3.59 with very valid criteria, where the suitability of trial 2 averaged 3.64 with very valid criteria. Overall, the developed e-LKPD obtained an average score of 3.60 with a very valid category. Novitas (2021) states that if a validity test is carried out to obtain very valid criteria, then the developed e-LKPD is good and appropriate. Cognitive learning outcomes are the final results obtained by students in their understanding of science related to mental processes (the brain). Besides it is also the basis for mastering knowledge that must be mastered by students after they have done a lesson. The assessment of students' cognitive learning outcomes was carried out through pretest and posttest in class XI MIPA 3. The results of the study are presented in Table 3. Chotimah (2018) suggests that learning resources that meet student needs and improve student learning outcomes are the appropriate learning resources in the learning process.

Table 3. Student Cognitive Learning Outcomes Based on Pretest and Posttest Scores

\begin{tabular}{lccccc}
\hline No & Category & Predicate & Interval & Pretest & Postest \\
\hline 1 & Very Good & A & 5 & - & 8 \\
2 & Good & B & 4 & - & 8 \\
3 & Enough & C & 3 & - & 3 \\
4 & Less & D & 2 & 20 & 1 \\
5 & Very Less & E & 1 & - & - \\
Number of Student & & & 20 & 20 \\
Average & & & 30,4 & 90,35 \\
Predicate & & & & D & B \\
Category & & & & Good \\
\hline
\end{tabular}

From Table 3, the average posttest score is 90.35 and B predicate in good category. There were 8 students who got A predicate in very good category, 8 students who got B predicate in good category, students who got B predicate. There were 3 students who got a $\mathrm{C}$ predicate in the sufficient category and 1 student who got a $\mathrm{D}$ predicate with a less category. While the average value of the pretest was 30.4 and the D category was less with the number of students 20 students in the less category. Firdaus (2018) stated that the comparison of student learning outcomes in the pretest and posttest experience a significant increase which can affect the learning resources used in the learning process. Based on the data increased in the Posttest value, the N-Gain value analysis was then carried 
out. It aims to interpret the criteria for improving the cognitive learning outcomes of students as a whole. The results of the $\mathrm{N}$-Gain analysis are presented in Table 4.

Table 4. Results of N-Gain Analysis for Improving Student Cognitive Learning Outcomes

\begin{tabular}{lcc}
\hline & Evaluation & Result \\
\hline Pre-Test & & 30,4 \\
Post-Test & & 90,35 \\
& N-Gain & $\mathbf{0 , 8 5}$ \\
& Description & High \\
\hline
\end{tabular}

According to Hake's (2007) classification, if the value of $\mathbf{n}$ gain is 0.70 , the $\mathrm{n}$-gain value is in the high classification. Then if the n-gain value is $0.30(\mathrm{~g}) 0.70$, then the $n$-gain value is in the medium classification. If $<0.30$ then it is classified as low. Based on this classification, the n-gain value in increasing the knowledge value on the Posttest score was quite high. The increase in cognitive learning outcomes was classified as high with an N-Gain value of 0.85. JK (2021) suggests that the effectiveness of using e-LKPD in the student learning process can increase the value of students' cognitive learning knowledge. Based on the increase in the value of cognitive learning outcomes in the application of the human circulatory system e-LKPD, it is known that learning using e-LKPD using the human circulatory system material learning model was able to improve students' cognitive learning outcomes, which the pretest has an average score of 30.4 and posttest has an average score of 90.3.

Based on the increase in the value of cognitive learning outcomes in the application of experimental e-LKPD using a guided inquiry learning model on the material of the human circulatory system, it was known that learning could improve students' cognitive learning outcomes. Maida (2019) states that student learning outcomes with guided inquiry learning make students able to guide students to find their own concepts and make practical activities more meaningful.

\section{Conclusion}

Experimental e-LKPD using a guided inquiry learning model on the material of the human circulatory system which was developed from the content validation aspect was very valid, and the practical aspect showed as very practical. There was an increase in students' cognitive learning outcomes after the application of the experimental e-LKPD using the guided inquiry learning model on the circulatory system material for class XI SMA.

\section{Thank-You Note}

The author thanks Dr. Wan Syafii, M.Si as supervisor I and Dr. Zulfarina, M.Si as supervisor II who has guided the author and provided knowledge to the author. 


\section{References}

Anggriyani, R., Lufri, L., \& Zulyusri, Z. (2013). Analisis Kegiatan Praktikum Biologi Kelas X dan XI SMAN 10 Padang Tahun Pelajaran 2012/2013. Kolaboratif, 1(1).

Astuti, Y., \& Setiawan, B. (2013). Pengembangan lembar kerja siswa (LKS) berbasis pendekatan inkuiri terbimbing dalam pembelajaran kooperatif pada materi kalor. Jurnal Pendidikan IPA Indonesia, 2(1).

Chotimah, C., Hendri, M., \& Rasmi, D. P. (2018). Penerapan LKS Berbasis Inkuiri Terbimbing pada Materi Listrik terhadap Hasil Belajar Siswa Kelas IX SMPN 22 Kota Jambi. Jurnal Penelitian Pembelajaran Fisika, 9(1), 36-39.

Firdaus, M., \& Wilujeng, I. (2018). Pengembangan LKPD inkuiri terbimbing untuk meningkatkan keterampilan berpikir kritis dan hasil belajar peserta didik. Jurnal Inovasi Pendidikan IPA, 4(1), 26-40.

Haqsari, R. (2014). Pengembangan dan Analisis E-LKPD (Elektronik-Lembar Kerja Peserta Didik) Berbasis Multimedia pada Materi Mengoperasikan Software Spreadsheet. Univ. Negeri Yogyakarta, 53, 1689-99.

Hidayati, N. (2012). Penerapan metode praktikum dalam Pembelajaran kimia untuk meningkatkan Keterampilan berfikir tingkat tinggi siswa Pada materi pokok kesetimbangan kimia kelas XI smk diponegoro banyuputih batang (Doctoral dissertation, IAIN Walisongo).

Hotimah, H. (2008). Penerapan model pembelajaran IPA terpadu bervisi SETS untuk meningkatkan hasil belajar siswa SMP (Doctoral dissertation, Universitas Negeri Semarang).

Ikhwani, P. N., \& Kuntjoro, S. (2021). Pengembangan Lembar Kegiatan Peserta Didik Elektronik (e-LKPD) Berbasis Guided Inquiry pada Materi Perubahan Lingkungan Untuk Melatihkan Keterampilan Berpikir Kritis Siswa Kelas X Sma. Berkala Ilmiah Pendidikan Biologi (BioEdu), 10(3), 597-604.

Illahi, N. R., \& Hariani, D. (2021). Validitas LKPD Berbasis Inkuiri Terbimbing untuk Melatihkan Keterampilan Proses Sains pada Submateri Sistem Indera Kelas XI SMA. Berkala Ilmiah Pendidikan Biologi (BioEdu), 10(1), 102-112.

JK, A. K. R. (2021). Pengembangan Lembar Kerja Peserta Didik Elektronik (ELKPD) Berbasis Inkuiri pada Submateri Fotosintesis untuk Meningkatkan Kemampuan Argumentasi Peserta Didik. Berkala Ilmiah Pendidikan Biologi (BioEdu), 10(3), 663-673.

Maida, M. C., Bayharti, B., \& Andromeda, A. (2019). Pengaruh Penggunaan Lembar Kerja Siswa (LKS) Eksperimen Laju Reaksi Berbasis Inkuiri Terbimbing Terhadap Hasil Belajar Siswa Kelas XI MIA SMAN 4 Padang. Jurnal Eksakta Pendidikan (JEP), 3(1), 75-81.

Millar, Robin. (2009). Analyzing Practical Activities To Assess And Improve Effectiveness : The Practical Activity Abalysis Inventory ( Paai ) Vol 3, University of York.

Nasional, D. P. (2006). Pedoman Memilih dan Menyusun Bahan Ajar, Depdiknas: Jakarta.

Noer Rahmah. (2012). Psikologi Pendidikan, Teras: Yogyakarta. 
Novitasari, F. D., \& Budijastuti, W. (2021). Validitas Lembar Kegiatan Peserta Didik (LKPD) Berbasis Inkuiri Terbimbing pada Materi Perubahan Lingkungan untuk Melatihkan Keterampilan Proses Peserta Didik Kelas X SMA. Berkala Ilmiah Pendidikan Biologi (BioEdu), 10(1), 113-125.

Putria, A. N., Serevina, V., \& Budi, A. S. (2019, December). Lembar Kerja Elektronik Peserta Didik Dilengkapi Simulasi Phet Berbasis Inkuiri Terbimbing untuk Meningkatkan Penguasaan Konsep Fisika pada Siswa SMA. In Prosiding Seminar Nasional Fisika (E-Journal) (Vol. 8, pp. SNF2019-PE).

Permana, S. (2017). Pengembangan Lembar Kerja Peserta Didik (LKPD) Fisika Berbasis Inkuiri Terbimbing Berorientasi Nilai-Nilai Islami Pada Materi Alat-Alat Optik (Doctoral dissertation, IAIN RADEN INTAN LAMPUNG).

Sanjaya. (2014). Penelitian Pendidikan Jenis Metode dan Prosedur, Kencana Prenada Media Group: Jakarta.

Sugiyono. (2016). Metode Penelitian dan Pengembangan, Alfabeta: Bandung.

Suryana (2015). Metode Penelitian Model Praktis Penelitian Kualitatif dan Kuantitatif, UPI: Bandung.

Syamsiah, S., Danial, M., \& Hala, Y. (2019, December). Pengembangan Media Pembelajaran E-Modul Materi Sel Pada Kelas XI MIPA SMAN 3 Barru. In Seminar Nasional Biologi.

How to cite this article:

Seftiani, S., Syafii, W., \& Zulfarina. (2022). The Development of Experimental Electronic Student Activity Sheet (E-LKPD) using The Guided Inquiry Learning Model on Blood Circulation System Materials for Class XI SMA/MA. Journal of Educational Sciences, 6(1), 24-34. 